\title{
Reduced cortical renal GLUT1 expression induced by angiotensin-converting enzyme inhibition in diabetic spontaneously hypertensive rats
}

\author{
M.S. Souza1, U.F. Machado², M. Okamoto², M.C. Bertoluci ${ }^{3}$, C. Ponpermeyer ${ }^{1}$, \\ N. Leguisamo1 ${ }^{1}$ F. Azambuja1, M.C. Irigoyen ${ }^{1,4}$ and B.D. Schaan ${ }^{1,3}$ \\ ${ }^{1}$ Instituto de Cardiologia do Rio Grande do Sul, Fundação Universitária de Cardiologia, Porto Alegre, \\ RS, Brasil \\ 2Departamento de Fisiologia e Biofísica, Instituto de Ciências Biomédicas, Universidade de São Paulo, \\ São Paulo, SP, Brasil \\ ${ }^{3}$ Serviços de Endocrinologia e Medicina Interna, Hospital de Clínicas de Porto Alegre, Universidade \\ Federal do Rio Grande do Sul, Porto Alegre, RS, Brasil \\ 4Unidade de Hipertensão, Instituto do Coração, Faculdade de Medicina, Universidade de São Paulo, \\ São Paulo, SP, Brasil
}

Correspondence to: B.D. Schaan, Unidade de Pesquisa, IC/FUC, Av. Princesa Isabel, 370, 90620-001 Porto Alegre, RS, Brasil

Fax: +55-51-3219-2802. E-mail: bschaan.pesquisa@cardiologia.org.br

\begin{abstract}
Diabetes in spontaneously hypertensive rats is associated with cortical renal GLUT1 and GLUT2 overexpression. Our objective was to evaluate the effect of the angiotensin-converting enzyme blockade on cortical renal GLUT1 and GLUT2 expression, urinary albumin and urinary TGF- $\beta 1$. Streptozotocin, $50 \mathrm{mg} / \mathrm{kg}$, or citrate buffer $(\mathrm{N}=16)$ was administered as a single injection into the tail vein in adult spontaneously hypertensive rats $(\sim 260 \mathrm{~g})$. Thirty days later, these diabetic spontaneously hypertensive rats received ramipril by gavage: $0.01 \mathrm{mg} \cdot \mathrm{kg}^{-1} \cdot$ day $^{-1}(\mathrm{D} 0.01, \mathrm{~N}=14), 1 \mathrm{mg} \cdot \mathrm{kg}^{-1} \cdot \mathrm{day}^{-1}(\mathrm{D} 1, \mathrm{~N}=9)$ or water $(\mathrm{D}, \mathrm{N}=11)$ for $15 \mathrm{days}$. Albumin and TGF- $\beta 1$ (24-h urine), direct arterial pressure, renal tissue angiotensin-converting enzyme activity (fluorometric assay), and GLUT1 and GLUT2 protein levels (Western blot, renal cortex) were determined. Glycemia and glycosuria were higher $(P<0.05)$ in the diabetic rats compared with controls, but similar between the diabetic groups. Diabetes in spontaneously hypertensive rats lowered renal tissue angiotensin-converting enzyme activity (40\%), which was reduced further when higher ramipril doses were used. Diabetes associated with hypertension raised GLUT1 by $28 \%(P<0.0001)$ and GLUT2 by $76 \%(P=$ 0.01 ), and both doses of ramipril equally reduced cortical GLUT1 ( $D$ vs $D 1$ and vs D0.01, $P \leq 0.001$ ). GLUT2 levels were reduced in $\mathrm{D} 0.01(\mathrm{P}<0.05$ vs $\mathrm{D})$. Diabetes increased urinary albumin and TGF- $\beta 1$ urinary excretion, but the 15-day ramipril treatment (with either dose) did not reduce them. In conclusion, ramipril is effective in lowering renal tissue angiotensin-converting enzyme activity, as well as blocking cortical GLUT1 overexpression, which may be beneficial in arresting the development of diabetic nephropathy.
\end{abstract}

Key words: Angiotensin-converting enzyme inhibition; Diabetes mellitus; Diabetic nephropathy; Glucose transporter proteins; Hypertension; Streptozotocin

Publication supported by FAPESP, FAPERGS, CNPq, and FAPICC.

Received March 10, 2008. Accepted November 4, 2008 


\section{Introduction}

Diabetic nephropathy is the leading cause of renal failure in patients starting renal replacement therapy. The two main strategies for its prevention are to improve glycemic control and to lower blood pressure, especially by applying angiotensin-converting enzyme (ACE) inhibitors. The renoprotective effects of ACE inhibitors are believed to be independent of their reduction of systemic blood pressure (1) because of their specific effect in lowering intraglomerular pressure (2) and effects resulting from angiotensin II (AII) blockage.

Angiotensin II can be deleterious by causing systemic and intraglomerular hypertension and also by an effect on mesangial cells by directly stimulating their production of transforming growth factor- $\beta 1$ (TGF- $\beta 1$ ) (3). Elevated production and/or activity of TGF- $\beta 1$ in the kidney is a final common mediator of diabetic renal hypertrophy and mesangial matrix expansion (4). Mesangial stretch, induced by hypertension (5) and by hyperglycemia (6), can also increase TGF- $\beta 1$ production. Moreover, in diabetic rats high glucose itself may increase mesangial All generation increasing TGF- $\beta 1$ expression (3). We demonstrated that urinary TGF- $\beta 1$ is increased simultaneously with high GLUT1 and GLUT2 protein in the renal cortex of the streptozotocin (STZ)-induced diabetic rat (7).

Renal glucose reabsorption is a coordinated process, which takes place in the epithelial cells of the proximal tubule, involving two classes of glucose transporters, the $\mathrm{Na}^{+}$-glucose transporters (SGLTs) and facilitative diffusion transporters (GLUTs) (8). In the early S1 segment, where the bulk of filtered glucose is reabsorbed, the low affinity/ high capacity glucose transporters, SGLT2 and GLUT2 are co-expressed in the luminal brush border membrane and in the basolateral membrane, respectively. Increases in the cortical GLUT2 gene expression have been extensively reported in diabetes (9-15), and are important for renal glucose reabsorption maintenance in this condition, since high blood and interstitial glucose concentrations may lower the outwardly directed glucose gradient from tubule to blood (11). GLUT1 protein is also detected in the outer renal cortex, where it is not related to the tubule epithelial cells, but to the mesangial cells (16). It has been suggested that increased expression of cortical GLUT1 (mesangial cells) (7) and GLUT2 (S1 tubular cells) (14) is involved in the development and progression of diabetic nephropathy.

Subsequently, upregulation of cortical renal GLUT1 and GLUT2 levels and increased urinary TGF- $\beta 1$ and albumin excretion in genetically hypertensive diabetic rats have been reported (17). The major effect of hypertension on GLUT1 overexpression could be mediated by All, since it is elevated in the plasma of stroke-prone spontaneously hypertensive rats (SHR; 18) and, in vitro, it causes overexpression of GLUT1 in vascular smooth muscle (19) and in mesangial cells (20). The well-known diabetes-induced GLUT2 overexpression $(9,21,22)$ and the further rise that hypertension can determine in it (17) may promote, in addition to hyperglycemia, a further elevation in the interstitial renal glucose concentration, and more glucose is taken up by mesangial cells through GLUT1. However, the role of All on the GLUT1 and GLUT2 overexpression of SHR has not yet been explored.

An ACE-inhibitor used at low doses (non-anti-hypertensive) could facilitate the evaluation of the beneficial effects of these drugs, independent of their anti-hypertensive effect. Low doses of quinapril and ramipril were used before, and can effectively block the renin-angiotensin system (23). There is currently no report in the literature showing the effects of the inhibition of the renin-angiotensin system upon cortical renal GLUT1 and GLUT2 expression in vivo. Thus, we investigated whether the treatment of diabetic hypertensive rats with ramipril could modulate GLUT1 and GLUT2 expression.

\section{Material and Methods}

Experiments were performed on 2-month-old male SHR (Animal House of the Coordenação de Produção e Experimentação Animal, Fundação Estadual de Produção e Pesquisa em Saúde, Porto Alegre, RS, Brazil), weighing $\sim 260 \mathrm{~g}$, acclimatized for 1 week, fasted overnight and rendered diabetic (D) by a single injection of STZ (50 mg/ $\mathrm{kg}$, Sigma Chemical Co., USA) into the tail vein. STZ was dissolved in citrate buffer, $\mathrm{pH} 4.5$, and injected slowly. Non-diabetic rats (C) were injected with citrate buffer. Diabetes was defined as a non-fasting glucose $>250 \mathrm{mg} /$ $\mathrm{dL}$ in tail vein blood $48 \mathrm{~h}$ after STZ injection. The animals were maintained for 30 days in individual cages with free access to tap water and standard rat chow. They were then treated for 15 days with a low dose of ramipril $(0.01$ $\mathrm{mg} \cdot \mathrm{kg}^{-1} \cdot$ day $^{-1}, \mathrm{D} 0.01 ; \mathrm{N}=21$ ), a high dose of ramipril (1 $\mathrm{mg} \cdot \mathrm{kg}^{-1} \cdot \mathrm{day}^{-1}, \mathrm{D} 1 ; \mathrm{N}=18$ ) or water $(\mathrm{C}: \mathrm{N}=23$ and $\mathrm{D}: \mathrm{N}=$ $20)$, administered daily by gavage. Before and after this treatment, 24-h urine was collected in metabolic cages for glucose, albumin and TGF- $\beta 1$ analyses.

In 50 rats $(\mathrm{C}: \mathrm{N}=16$; $\mathrm{D}: \mathrm{N}=11$; $\mathrm{D} 0.01$ : $\mathrm{N}=14$; $\mathrm{D} 1$ : $N=9$ ), catheters (PE-10) filled with saline were implanted under anesthesia into the femoral artery for direct measurement of arterial pressure. One day later, the cannula was connected to a strain-gauge transducer (P23Db, Gould-Statham, USA) and arterial pres- 
sure signals were recorded for 20 min using a microcomputer with an analog-to-digital converter board (CODAS, 2-kHz sampling frequency, Dataq Instruments, Inc., USA). The rats were conscious and moved freely during the experiments. Recorded data were analyzed on a beat-to-beat basis. One day later, the animals were anesthetized with sodium pentobarbital $(25 \mathrm{mg} /$ $\mathrm{kg}$ body weight, iv) and their kidneys removed for measurement of ACE activity.

Thirty-two rats (C: $N=7 ; D: N=9$; D0.01: $N=7 ; D 1: N$ $=9$ ) had their kidneys removed for GLUT1 and GLUT2 protein content ( 45 days of diabetes, 15 days after ramipril or placebo treatment). They were anesthetized with sodium pentobarbital (25 $\mathrm{mg} / \mathrm{kg}$ body weight, $i \mathrm{v})$, their kidneys were perfused with Hanks' buffer, to eliminate the intravascular blood content, and removed. Renal outer cortex and outer medulla were dissected and the tissue fragments of each area ( $1.5 \mathrm{~mm}$ slices) were weighed and frozen at $-70^{\circ} \mathrm{C}$ for further analysis.

The experimental protocol was approved by the Ethics Committee for Animal Research of Instituto de Cardiologia do Rio Grande do Sul, and the studies were conducted in accordance with the National Institutes of Health (NIH) Guide for the Care and Use of Laboratory Animals (http:// dels.nas.edu/ilar_n/ilarhome/).

\section{Glucose, albumin and TGF- $\beta 1$}

Glycemia was evaluated $48 \mathrm{~h}$ and 45 days after STZI citrate buffer injection (test strips, Advantage, Roche, USA). Urinary glucose was measured using the colorimetric enzymatic test (commercial kit, Merck, Germany, Centrifichem System 400-Roche/Cobas Mira-Roche).

Samples for the measurement of urinary albumin were collected without preservatives and stored at $-70^{\circ} \mathrm{C}$ after centrifugation. Albuminuria was measured by a quantitative direct competitive enzyme-linked immunosorbent assay (ELISA; Nephrat, Exocell Inc., USA) using a highly specific anti-rat albumin antibody. The quantification range for albuminuria was $0.156-10 \mathrm{mg} / \mathrm{dL}$. Samples were diluted 1:10 (controls) and 1:2 (diabetics). Results are reported as $\mathrm{mg} / 24 \mathrm{~h}$.

Urinary TGF- $\beta 1$ was assayed by solid phase ELISA (R\&D Systems, UK). Urine samples were collected on ice and centrifuged at $10,000 \mathrm{rpm}$ for $30 \mathrm{~min}$ at $4^{\circ} \mathrm{C}$. Supernatant was removed and stored at $-70^{\circ} \mathrm{C}$. On the day of the assay, samples $(0.5 \mathrm{~mL})$ were acidified to a $\mathrm{pH}$ of 2-3 with $100 \mu \mathrm{L} 1 \mathrm{~N} \mathrm{HCL}$ for $10 \mathrm{~min}$ and then reneutralized to $\mathrm{pH} 7-8$ with $100 \mu \mathrm{L} 1.2 \mathrm{~N} \mathrm{NaOH} / 0.5 \mathrm{M}$ HEPES. Results are reported as ng/24 h. The mean intraand interassay coefficients of variation were 2.0 and $13.1 \%$, respectively.

\section{Angiotensin-converting enzyme activity}

ACE activity was determined using the fluorometric assay (24). One kidney was quickly harvested, rinsed, blotted and homogenized in $0.4 \mathrm{M}$ sodium borate buffer, $\mathrm{pH}$ 7.2. Supernatants from homogenized tissues $(20 \mu \mathrm{L})$ were incubated with 490 or $480 \mu \mathrm{L}$ assay buffer containing $5 \mathrm{mM}$ Hip-His-Leu in $0.4 \mathrm{M}$ sodium borate buffer and $0.9 \mathrm{M}$ $\mathrm{NaCl}, \mathrm{pH} 8.3$, for 15 or $30 \mathrm{~min}$ at $37^{\circ} \mathrm{C}$. The reaction was stopped by the addition of $1.2 \mathrm{~mL} 0.34 \mathrm{M} \mathrm{NaOH}$. The product, His-Leu, was measured fluorometrically at 365$\mathrm{nm}$ excitation and 495-nm emission with a fluorescence spectrometer (Shimadzu, RF 1501, Japan). o-Phthaldialdehyde (100 $\mu \mathrm{L}, 20 \mathrm{mg} / \mathrm{mL})$ in methanol was added, and after 10 min the solution was acidified with $200 \mu \mathrm{L} 3 \mathrm{~N} \mathrm{HCl}$ and centrifuged at $3000 \mathrm{rpm}$ for $10 \mathrm{~min}$ at room temperature. To correct for the intrinsic fluorescence of the tissues, time zero blanks were prepared by adding tissue after $\mathrm{NaOH}$. The sensitivity of the assay was $\leq 0.02 \mathrm{nmol} \cdot \mathrm{mg}$ tissue ${ }^{-1} \cdot \mathrm{min}^{-1}$; the fluorescence intensity was linear with the concentration of His-Leu generated from 0.02 to 15 $\mathrm{nmol} \cdot \mathrm{mg}$ tissue ${ }^{-1} \cdot \mathrm{min}^{-1}$. The results are reported as $\mathrm{nmol}$ His-Leu min $^{-1} \cdot$ mg protein $^{-1}$, measured with Bradford's method (25) (bovine serum albumin as the standard).

\section{GLUT1 and GLUT2}

Renal cortex was analyzed for GLUT1 and GLUT2 protein content and renal medulla was analyzed for GLUT1 protein content. Anti-sera against GLUT1 and GLUT2 were raised in male New Zealand rabbits, and have been successfully used for immunoblotting $(17,21)$.

The tissue samples were homogenized in $10 \mathrm{w} / \mathrm{v}$ buffer (10 mM) Tris- $\mathrm{HCl}, 1 \mathrm{mM}$ EDTA, and $250 \mathrm{mM}$ sucrose, $\mathrm{pH}$ 7.4 , containing $5 \mathrm{mg} / \mathrm{mL}$ aprotinin, and centrifuged at 3000 $g$ for $15 \mathrm{~min}$. The supernatant was centrifuged at $12,000 \mathrm{~g}$ for $20 \mathrm{~min}$, and the pellet was re-suspended as a plasma membrane fraction, in which the $5^{\prime}$ nucleotidase (plasma membrane marker) and alkaline phosphatase (brush border membrane marker) activities were shown to be more than six and three times increased, respectively, compared with the enzyme activity in the supernatant of the first centrifugation. Western blot analysis was then performed as previously described $(17,21)$. Briefly, equal amounts of membrane protein $(100 \mu \mathrm{g}$ from medulla and $150 \mu \mathrm{g}$ from cortex samples) were subjected to SDSPAGE (10\%) and transferred by electrophoresis to nitrocellulose paper. After blocking with non-fat milk, the sheets were incubated with the specific antiserum, followed by washing and incubation with (125l)-protein A (Amersham Pharmacia Biotech, UK). After a final wash, the nitrocellulose sheets were dried at room temperature, and exposed to an X-ray film for 5 days at $-70^{\circ} \mathrm{C}$. The blots were 
quantified by measuring absorbance using the Image Master ID ${ }^{\circledR}$ software (Pharmacia Biotech, Sweden). The results were normalized considering the mean of the values of control animals (SHR) in each membrane as 100, and reported as arbitrary units.

\section{Data analysis}

Data are reported as means \pm SEM. Statistical significance was calculated by one-way ANOVA, and by the post hoc Student-Newman-Keuls test. Urinary albumin and TGF$\beta 1$ data were log-transformed before analysis. Statistical significance was defined at the 0.05 level.

\section{Results}

Table 1 shows the characteristics of the rats studied. Body weights were similar between groups at baseline. Thirty and 45 days after the STZ injection, body weights were lower in rats of groups D, D0.01, and D1 compared with controls. Plasma and urinary glucose levels and urinary volume were higher in the diabetic rats compared with controls, showing the efficacy of the diabetes induction. Weight, glycemia, urine volume, and glycosuria were simi- lar between the diabetic groups 45 days after STZ. Therefore, no differences in these variables could be attributed to different ramipril doses between groups.

The results concerning renal tissue ACE activity are reported in Figure 1. Diabetes caused lower (40\%) renal tissue ACE activity levels compared with $C(P<0.001)$. As expected, reduced ACE activity was also observed in the ramipril-treated rats. ACE activity levels were progressively lower as the dose of ACE inhibitor increased. Compared to group D rats, renal tissue ACE activity was $59 \%$ lower in group $D 1$ rats $(P<0.0001)$.

All groups displayed high mean arterial pressure levels, a characteristic of the animal model employed. Streptozotocin did not affect mean arterial pressure, but ramipril caused significantly lower $(P<0.05)$ mean arterial pressure levels in D0.01 and D1 rats in comparison with $D$ and $C$ rats $(164 \pm 6,159 \pm 5,145 \pm 5$, and $137 \pm 8 \mathrm{mmHg}$ in $\mathrm{C}$, $\mathrm{D}, \mathrm{D} 0.01$, and D1, respectively). Although the average arterial pressure levels were apparently lower in the D1 rats, they were not statistically different from those in D0.01 rats. Heart rate was similar between groups (386 \pm $9,359 \pm 12,370 \pm 27$, and $325 \pm 21 \mathrm{bpm}$ in groups $C, D$, D0.01, and D1, respectively; P > 0.05)

Table 1. Characteristics of diabetic hypertensive rats treated with ramipril.

\begin{tabular}{lcccc}
\hline & $C(\mathrm{~N}=16)$ & $\mathrm{D}(\mathrm{N}=11)$ & $\mathrm{D} 0.01(\mathrm{~N}=14)$ & $\mathrm{D} 1(\mathrm{~N}=9)$ \\
\hline Initial weight $(\mathrm{g})$ & $263 \pm 5$ & $265 \pm 4$ & $263 \pm 4$ & $264 \pm 4$ \\
30-day weight $(\mathrm{g})$ & $302 \pm 4$ & $249 \pm 7^{*}$ & $237 \pm 8^{*}$ & $239 \pm 7^{*}$ \\
45-day weight $(\mathrm{g})$ & $316 \pm 4$ & $247 \pm 7^{*}$ & $233 \pm 8^{*}$ & $234 \pm 8^{*}$ \\
48-h glycemia $(\mathrm{mg} / \mathrm{dL})$ & $111 \pm 5$ & $461 \pm 17^{*}$ & $429 \pm 15^{*}$ & $444 \pm 19^{*}$ \\
45-day glycemia $(\mathrm{mg} / \mathrm{dL})$ & $96 \pm 4$ & $403 \pm 23^{*}$ & $394 \pm 25^{*}$ & $419 \pm 19^{*}$ \\
45-day glycosuria $(\mathrm{mg} / 24 \mathrm{~h})$ & $1.1 \pm 0.6$ & $5191 \pm 878^{*}$ & $6154 \pm 679^{*}$ & $6031 \pm 752^{*}$ \\
45-day diuresis $(\mathrm{mL} / 24 \mathrm{~h})$ & $12 \pm 0.8$ & $76 \pm 5^{*}$ & $79 \pm 4^{*}$ & $83 \pm 5^{*}$ \\
\hline
\end{tabular}

Data are reported as means \pm SEM. $C=$ control non-diabetic spontaneously hypertensive rats; $D=$ diabetic spontaneously hypertensive rats; $\mathrm{D} 0.01$ = diabetic spontaneously hypertensive rats treated with $0.01 \mathrm{mg} / \mathrm{kg}$ ramipril daily for 15 days; $\mathrm{D} 1=$ diabetic spontaneously hypertensive rats treated with $1 \mathrm{mg} / \mathrm{kg}$ ramipril daily for 15 days. ${ }^{*} \mathrm{P}<0.05$ vs C (ANOVA and post hoc StudentNewman-Keuls test).

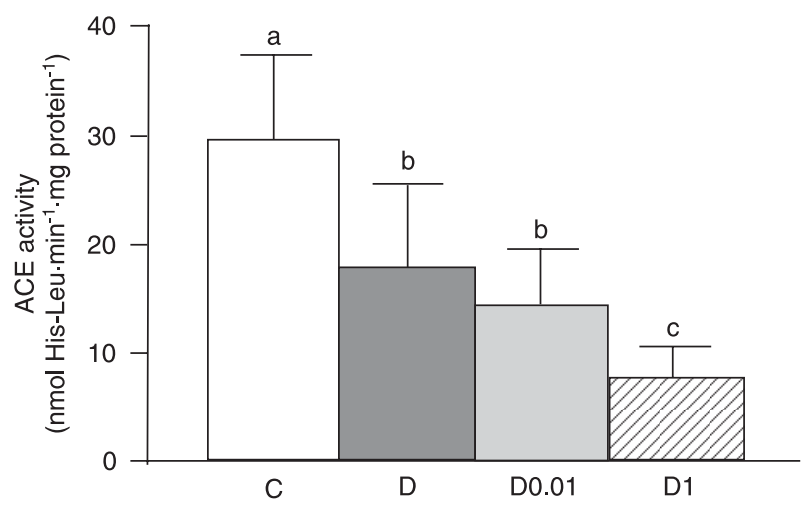

Figure 1. Kidney angiotensin-converting enzyme (ACE) activity in non-diabetic spontaneously hypertensive rats $(C, N=9)$ and diabetic spontaneously hypertensive rats not treated with ramipril $(\mathrm{D}, \mathrm{N}=10)$ or treated with ramipril $0.01 \mathrm{mg} \cdot \mathrm{kg}^{-1} \cdot$ day $^{-1}(\mathrm{D} 0.01, \mathrm{~N}$ $=11$ ) and $1 \mathrm{mg} \cdot \mathrm{kg}^{-1} \cdot \mathrm{day}^{-1}(\mathrm{D} 1, \mathrm{~N}=10)$. Data are reported as mean \pm SEM. Different letters indicate statistically significant differences between groups $(P<0.001$, post hoc Student-Newman-Keuls test). 
Albuminuria and urinary TGF- $\beta 130$ days after the STZ injection are reported in Table 2. Albuminuria increased by 3 times in group $D$ rats $(P<0.0001)$, and urinary TGF- $\beta 1$ excretion was 7.3 times higher $(P<0.0001)$ in the same animals compared with controls. The evaluation performed 15 days after the ACE blockage with ramipril ( 45 days after the STZ injection) indicated no change in albuminuria and urinary TGF- $\beta 1$ in relation to controls at the doses employed.

Figure $2 \mathrm{~A}$ shows that diabetes caused higher $(28 \%)$ cortical GLUT1 expression in hypertensive rats $(P<0.0001)$. Ramipril treatment reduced this effect significantly at both

Table 2. Effect of diabetes and ramipril administration on rat urinary albumin and TGF- $\beta 1$.

\begin{tabular}{lcccc}
\hline & $\mathrm{C}(\mathrm{N}=16)$ & \multicolumn{2}{c}{$\mathrm{D}(\mathrm{N}=34)$} & \\
\cline { 2 - 5 } 30-day urinary albumin $(\mathrm{mg} / 24 \mathrm{~h})$ & $\begin{array}{c}33.0(24.5-82.3) \\
\text { 30-day urinary TGF- } \beta 1(\mathrm{ng} / 24 \mathrm{~h})\end{array}$ & $\begin{array}{c}148.0(100.0-259.0)^{*} \\
\end{array}$ & & \\
\hline & $\mathrm{C}(\mathrm{N}=16)$ & $\mathrm{D}(\mathrm{N}=11)$ & $\mathrm{D} 0.01(\mathrm{~N}=14)$ & $\mathrm{D} 1(\mathrm{~N}=9)$ \\
\hline 45-day urinary albumin $(\mathrm{mg} / 24 \mathrm{~h})$ & $43.0(28.0-109.0)$ & $147.5(136.5-245.5)^{*}$ & $189.0(161.3-310.3)^{*}$ & $183.0(150.0-259.0)^{*}$ \\
45-day urinary TGF- $\beta 1(\mathrm{ng} / 24 \mathrm{~h})$ & $451.0(252.2-853.5)$ & $3040.5(2149.3-3155.0)^{*}$ & $2625.0(1615.3-3903.3)^{*}$ & $3377.0(2473.0-4988.0)^{*}$
\end{tabular}

Data are reported as median and $25-75 \%$. TGF- $\beta 1=$ transforming growth factor- $\beta 1 ; C=$ control non-diabetic spontaneously hypertensive rats; $\mathrm{D}=$ diabetic spontaneously hypertensive rats; $\mathrm{D} 0.01$ = diabetic spontaneously hypertensive rats treated with $0.01 \mathrm{mg} / \mathrm{kg}$ ramipril daily for 15 days; $\mathrm{D} 1$ = diabetic spontaneously hypertensive rats treated with $1 \mathrm{mg} / \mathrm{kg}$ ramipril daily for 15 days. ${ }^{*} \mathrm{P}<0.0001 \mathrm{vs} \mathrm{C}$ (Student $t$-test for comparisons between 30-day data and ANOVA/post hoc Student-Newman-Keuls test for comparisons between 45-day data).
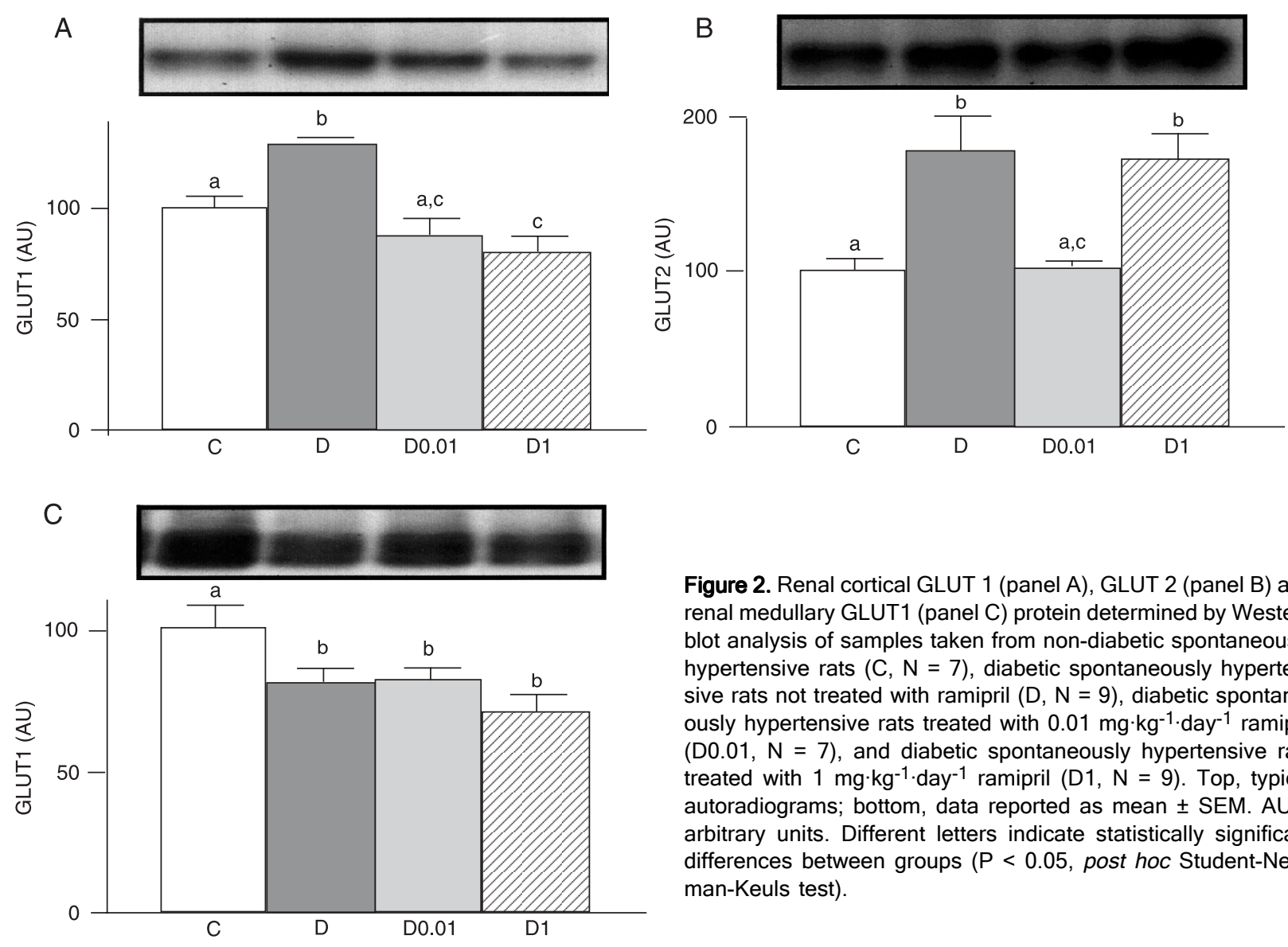

Figure 2. Renal cortical GLUT 1 (panel A), GLUT 2 (panel B) and renal medullary GLUT1 (panel C) protein determined by Western blot analysis of samples taken from non-diabetic spontaneously hypertensive rats $(C, N=7)$, diabetic spontaneously hypertensive rats not treated with ramipril $(D, N=9)$, diabetic spontaneously hypertensive rats treated with $0.01 \mathrm{mg} \cdot \mathrm{kg}^{-1} \cdot$ day $^{-1}$ ramipril (D0.01, N = 7), and diabetic spontaneously hypertensive rats treated with $1 \mathrm{mg} \cdot \mathrm{kg}^{-1} \cdot \mathrm{day}^{-1}$ ramipril (D1, N = 9). Top, typical autoradiograms; bottom, data reported as mean $\pm \mathrm{SEM}$. $\mathrm{AU}=$ arbitrary units. Different letters indicate statistically significant differences between groups $(P<0.05$, post hoc Student-Newman-Keuls test). 
doses employed, the levels of D1 rats being lower than that observed in non-diabetic rats (D1 vs $\mathrm{C}, \mathrm{P}<0.05)$. However, there was no difference in cortical GLUT1 protein expression induced by the different intensities of ACE inhibition (D0.01 vs D1, $P=0.500$ ). Figure 2B shows the GLUT2 protein results. The association of diabetes with hypertension caused a $76 \%$ increase in cortical GLUT2 content $(P<0.05)$. Ramipril normalized these levels in the D0.01 group ( $D$ vs D0.01, $\mathrm{P}<0.05$; $C$ vs $\mathrm{D} 0.01, \mathrm{P}=0.89$ ). Surprisingly, high doses of the drug did not further decrease these levels; instead, cortical GLUT2 protein levels of the D1 group were similar to those of the $D$ group ( $D$ vs $\mathrm{D} 1, \mathrm{P}=0.91 ; \mathrm{C}$ vs $\mathrm{D} 1, \mathrm{P}<0.001)$. Medullary GLUT1 protein was similarly reduced by diabetes in the 3 diabetic groups compared with $\mathrm{C}$ ( $\mathrm{D}$ vs $\mathrm{C}$ and $\mathrm{D} 0.01$ vs $\mathrm{C}, \mathrm{P}<0.05$; D1 vs $\mathrm{C}, \mathrm{P}<0.01$, Figure $2 \mathrm{C}$ ).

\section{Discussion}

The major findings were: 1) diabetes in SHR caused a decrease in renal tissue ACE activity, no reduction in mean arterial pressure levels, but higher renal GLUT1 and GLUT2, urinary albumin and TGF- $\beta 1$ excretion; 2) $0.01 \mathrm{mg} / \mathrm{kg}$ ramipril in the STZ-hypertensive rats decreased renal tissue ACE activity, mean arterial pressure levels, renal GLUT1 and GLUT2, but did not change urinary albumin and TGF- $\beta 1$ excretion; 3) $1 \mathrm{mg} / \mathrm{kg}$ ramipril induced lower renal tissue ACE activity than the $0.01 \mathrm{mg} / \mathrm{kg}$ dose did, but mean arterial pressure and GLUT1 reductions were similar with both doses with no effect upon renal GLUT2 expression, urinary albumin or TGF- $\beta 1$ levels. This is the first study showing that the inhibition of ACE in the kidney can down-regulate GLUT1 in the STZ-diabetic-hypertensive rat.

The ramipril dose of $0.01 \mathrm{mg} / \mathrm{kg}$ did not affect arterial pressure in non-diabetic SHR in a study by Linz et al. (23), but lowered mean arterial pressure of diabetic animals in our study. We hypothesize that the volume-depleted state, characteristic of uncontrolled diabetes, allowed a depressor effect of ramipril even at doses that are non-antihypertensive in non-diabetic rats. Indeed, higher arterial pressure response to NO-synthase inhibition (26) and to chronic salt loading (27) was previously shown by us in diabetic rats, compared with non-diabetic rats, possibly related to volume-dependent and salt-sensitive mechanisms. Methodological problems (inadequacy of the administered doses) were discarded because we administered ramipril by gavage and the renal tissue ACE activity clearly distinguished the experimental groups.

Although there is evidence showing a positive relationship between the development of hypertension and local tissue ACE activity (28), in the present study diabetes and hypertension in association lowered renal tissue ACE activity, which has already been reported in STZ-diabetic Wistar rats (29), STZ-diabetic SHR (30) and genetic models of diabetes (31). Moreover, higher doses of ramipril in diabetic rats progressively lowered tissue ACE activity even more, as was expected and shown before with other drugs of the same class (32).

The additive effect of hyperglycemia and high arterial pressure levels upon cortical GLUT1, GLUT2, albuminuria, and urinary TGF- $\beta 1$ overexpression was previously shown by us (17), and these findings were confirmed by the present study. Stimulation of the matrix extracellular protein synthesis by the mesangial cell in response to increased cellular metabolism of glucose occurs as a consequence of chronically increased interstitial concentration of the substrate (4). GLUT1, the main glucose transporter in these cells, has a low Km for glucose $(\sim 1$ $\mathrm{mM})$, thus, within the physiological glucose levels, the glucose transport rate is already maximal. The only way by which glucose transport rate may rise is by modulating the amount of the glucose transporter $(7,33)$. Overexpression of GLUT2 intensifies tubular glucose reabsorption, leading to higher interstitial concentrations of glucose, so that more glucose is available to mesangial cells, GLUT1 overexpression is induced, more glucose is taken up by the mesangial cells and, finally, acceleration of the well-known intracellular steps involved in the pathogenesis of diabetic nephropathy occurs (9).

Concerning medullary GLUT1 levels, we showed before (17) that diabetes in SHR did not induce its welldescribed effect of reducing medullary GLUT1 (7). However, in the present study, diabetes induced a significant reduction of medullary GLUT1 in SHR, which may be related to the longer duration and severity of hyperglycemia. Moreover, neither ACE inhibition, nor arterial pressure lowering affected the levels of this glucose transporter, suggesting that at this site (medulla) the GLUT1 expression is controlled by other mechanisms, probably related to the hyperglycemia, which was unchanged among the diabetic groups.

There was a clear beneficial effect of cortical GLUT2 reduction induced by $0.01 \mathrm{mg} / \mathrm{kg}$ ramipril, but, surprisingly, this effect was lost as animals received higher doses and lower renal ACE was obtained. By treating the diabetichypertensive rats with $1 \mathrm{mg} / \mathrm{kg}$ ramipril, GLUT2 levels returned to the previous high levels, which even further lowered renal tissue ACE activity. This indicates that the GLUT2 modulation was not related to the lower arterial pressure, but to the renin-angiotensin-system blockage itself. In experimental diabetic nephropathy, it was already 
shown that low doses of ramipril - the same used in this experiment - do not inhibit the urinary excretion of bradykinin; however, high doses of the drug can definitely reduce this kinin urinary excretion, thus increasing its concentration in the renal tissue (34). Considering that bradykinin is involved in the ACE-induced $\beta$-adrenergic receptor upregulation (35), and that increased sympathetic activity can increase renal GLUT2 expression (9), we hypothesize that the reduced GLUT2 expression by ramipril was overbalanced by increased sympathetic tissue activity when high doses were used. The clear effect of $0.01 \mathrm{mg} / \mathrm{kg}$ ramipril in reducing GLUT2 could be lost as animals received higher doses and lower renal ACE was obtained, because other metabolic routes could provide additional All, as previously described in other tissues (36). This finding points out that low-dose ACE inhibitors provide the best effect upon renal GLUT2 modulation.

Interestingly, $0.01 \mathrm{mg} / \mathrm{kg}$ ramipril, which lowered renal tissue ACE activity (additively to the diabetes effect), reduced cortical renal GLUT1 and GLUT2 content, pointing to a possible modulation of these glucose transporters by ACE blockade and/or arterial pressure lowering. In vitro data suggested an All modulation of GLUT1 levels in vascular smooth muscle (19) and in mesangial cells (20), but no study established the relationship between renal glucose transporters and All or arterial pressure lowering in vivo. We were not able to define if the GLUT1 downregulation was caused by the renal $A C E$ inhibition, by the arterial pressure lowering, or by both, because there was no non-ACE anti-hypertensive control group, as we could show before for urinary TGF- $\beta 1$ in patients with diabetic nephropathy (37). However, mechanical stretch imposed by systemic hypertension on glomerular structure can itself promote overexpression of GLUT1, a mechanism that involves TGF- $\beta 1$ signaling activation, suggesting that lowered arterial pressure levels observed in the present

\section{References}

1. Lewis EJ, Hunsicker LG, Bain RP, Rohde RD. The effect of angiotensin-converting-enzyme inhibition on diabetic nephropathy. The Collaborative Study Group. N Engl J Med 1993; 329: 1456-1462.

2. Christensen PK, Lund S, Parving $\mathrm{HH}$. Autoregulated glomerular filtration rate during candesartan treatment in hypertensive type 2 diabetic patients. Kidney Int 2001; 60: 1435-1442.

3. Singh R, Alavi N, Singh AK, Leehey DJ. Role of angiotensin II in glucose-induced inhibition of mesangial matrix degradation. Diabetes 1999; 48: 2066-2073. study may be involved in the observed reduction of GLUT1. These data reinforce the mechanical stretch role in diabetic nephropathy pathogenesis and the importance of metabolic-hemodynamic interaction. The reduction in the GLUT1 protein content certainly decreases the cellular glucose disposal, which contributes to reduction in the extracellular matrix production. Whether this mechanism is able to revert established damage or not will depend on the reversibility of the changes, but it certainly can decelerate the progression of nephropathy.

Albuminuria and urinary TGF- $\beta 1$ were both clearly elevated by high arterial pressure associated with hyperglycemia, as already described (17), but neither marker decreased by lowering arterial pressure with an ACE inhibitor. We can postulate that the maintenance of very high glycemia levels continued to stimulate TGF- $\beta 1$ in mesangial cells, because TGF- $\beta 1$ is highly stimulated by increased glucose exposition. Also, it is possible that longer periods of ACE inhibition could be necessary to disclose benefits upon albuminuria and urinary TGF- $\beta 1$ levels, despite the persistent hyperglycemia. In the same model, 12-week tight blood pressure control instituted before the development of hypertension effectively reduced albuminuria levels and renal fibronectin (38), a protocol clearly different from ours concerning the beginning before kidney lesion was started and the longer duration of treatment.

Ramipril is effective in lowering renal tissue ACE activity and GLUT1 expression in diabetic SHR, an effect probably mediated by both the renin-angiotensin-system blockade and arterial pressure lowering. Moreover, the low dose of ramipril effectively reduced the renal cortical GLUT2 content to a non-diabetic level, which, surprisingly, was not observed with the high dose. Further investigation evaluating longer periods of ACE inhibition, comparison with a non-ACE inhibitor, and effects of additionally lowering glycemia is required.

4. Sharma K, Ziyadeh FN. Biochemical events and cytokine interactions linking glucose metabolism to the development of diabetic nephropathy. Semin Nephrol 1997; 17: 80-92.

5. Gruden G, Zonca S, Hayward A, Thomas S, Maestrini S, Gnudi $L$, et al. Mechanical stretch-induced fibronectin and transforming growth factor-beta1 production in human mesangial cells is p38 mitogen-activated protein kinase-dependent. Diabetes 2000; 49: 655-661.

6. Ziyadeh FN, Sharma K, Ericksen M, Wolf G. Stimulation of collagen gene expression and protein synthesis in murine mesangial cells by high glucose is mediated by autocrine 
activation of transforming growth factor-beta. J Clin Invest 1994; 93: 536-542.

7. D'Agord SB, Lacchini S, Bertoluci MC, Irigoyen MC, Machado UF, Schmid H. Increased renal GLUT1 abundance and urinary TGF-beta 1 in streptozotocin-induced diabetic rats: implications for the development of nephropathy complicating diabetes. Horm Metab Res 2001; 33: 664-669.

8. Thorens B. Glucose transporters in the regulation of intestinal, renal, and liver glucose fluxes. Am J Physiol 1996; 270: G541-G553.

9. Schaan BD, Irigoyen MC, Lacchini S, Moreira ED, Schmid $\mathrm{H}$, Machado UF. Sympathetic modulation of the renal glucose transporter GLUT2 in diabetic rats. Auton Neurosci 2005; 117: 54-61.

10. Marks J, Carvou NJ, Debnam ES, Srai SK, Unwin RJ. Diabetes increases facilitative glucose uptake and GLUT2 expression at the rat proximal tubule brush border membrane. J Physiol 2003; 553: 137-145.

11. Dominguez JH, Camp K, Maianu L, Feister H, Garvey WT. Molecular adaptations of GLUT1 and GLUT2 in renal proximal tubules of diabetic rats. Am J Physiol 1994; 266: F283F290.

12. Dominguez JH, Camp K, Maianu L, Garvey WT. Glucose transporters of rat proximal tubule: differential expression and subcellular distribution. Am J Physiol 1992; 262: F807F812.

13. Chin E, Zamah AM, Landau D, Gronbcek H, Flyvbjerg A, LeRoith $D$, et al. Changes in facilitative glucose transporter messenger ribonucleic acid levels in the diabetic rat kidney. Endocrinology 1997; 138: 1267-1275.

14. Vestri S, Okamoto MM, de Freitas HS, Aparecida Dos Santos R, Nunes MT, Morimatsu M, et al. Changes in sodium or glucose filtration rate modulate expression of glucose transporters in renal proximal tubular cells of rat. $J$ Membr Biol 2001; 182: 105-112.

15. Goestemeyer AK, Marks J, Srai SK, Debnam ES, Unwin RJ. GLUT2 protein at the rat proximal tubule brush border membrane correlates with protein kinase $C$ (PKC)-betal and plasma glucose concentration. Diabetologia 2007; 50: 22092217.

16. Li Y, Liu Z, Liu D, Zhang J, Chen Z, Li L. Identification and function of glucose transporter 1 in human mesangial cells. Chin Med J 2001; 114: 824-828.

17. Schaan BD, Irigoyen MC, Bertoluci MC, Lima NG, Passaglia $\mathrm{J}$, Hermes E, et al. Increased urinary TGF-beta1 and cortical renal GLUT1 and GLUT2 levels: additive effects of hypertension and diabetes. Nephron Physiol 2005; 100: 4350 .

18. Obata J, Nakamura T, Takano $H$, Naito A, Kimura $H$, Yoshida $Y$, et al. Increased gene expression of components of the renin-angiotensin system in glomeruli of genetically hypertensive rats. $J$ Hypertens 2000; 18: 1247-1255.

19. Quinn LA, McCumbee WD. Regulation of glucose transport by angiotensin II and glucose in cultured vascular smooth muscle cells. J Cell Physiol 1998; 177: 94-102.

20. Nose A, Mori $Y$, Uchiyama-Tanaka $Y$, Kishimoto N, Maruyama K, Matsubara $\mathrm{H}$, et al. Regulation of glucose transporter (GLUT1) gene expression by angiotensin II in mesangial cells: involvement of HB-EGF and EGF receptor transactivation. Hypertens Res 2003; 26: 67-73.

21. Freitas HS, Schaan BD, Seraphim PM, Nunes MT, Macha- do UF. Acute and short-term insulin-induced molecular adaptations of GLUT2 gene expression in the renal cortex of diabetic rats. Mol Cell Endocrinol 2005; 237: 49-57.

22. Freitas HS, D'Agord SB, da Silva RS, Okamoto MM, Oliveira-Souza M, Machado UF. Insulin but not phlorizin treatment induces a transient increase in GLUT2 gene expression in the kidney of diabetic rats. Nephron Physiol 2007; 105: 42-51.

23. Linz W, Jessen $T$, Becker RH, Scholkens BA, Wiemer G. Long-term ACE inhibition doubles lifespan of hypertensive rats. Circulation 1997; 96: 3164-3172.

24. Santos RA, Krieger EM, Greene LJ. An improved fluorometric assay of rat serum and plasma converting enzyme. Hypertension 1985; 7: 244-252.

25. Bradford MM. A rapid and sensitive method for the quantitation of microgram quantities of protein utilizing the principle of protein-dye binding. Anal Biochem 1976; 72: 248-254.

26. Balbinott $A W$, Irigoyen MC, Brasileiro-Santos MS, Zottis B, de Lima NG, Passaglia J, et al. Dose-dependent autonomic dysfunction in chronic L-NAME-hypertensive diabetic rats. J Cardiovasc Pharmacol 2005; 46: 563-569.

27. Maeda CY, Schaan BD, Oliveira EM, Oliveira VL, De Angelis $\mathrm{K}$, Irigoyen MC. Chronic salt loading and cardiovascularassociated changes in experimental diabetes in rats. Clin Exp Pharmacol Physiol 2007; 34: 574-580.

28. Sharifi AM, Akbarloo N, Darabi R, Larijani B. Study of correlation between elevation of blood pressure and tissue ACE activity during development of hypertension in $1 \mathrm{~K} 1 \mathrm{C}$ rats. Vascul Pharmacol 2004; 41: 15-20.

29. Maeda S, Kikkawa R, Haneda M, Togawa M, Koya D, Horide $\mathrm{N}$, et al. Reduced activity of renal angiotensin-converting enzyme in streptozotocin-induced diabetic rats. $J$ Diabet Complications 1991; 5: 225-229.

30. Handa H, Sakurama S, Nakagawa S, Yasukouchi T, Sakamoto W, Izumi H. Glandular kallikrein, renin and angiotensin converting enzyme of diabetic and hypertensive rats. Adv Exp Med Biol 1989; 247B: 443-448.

31. Ye M, Wysocki J, Naaz P, Salabat MR, LaPointe MS, Batlle D. Increased ACE 2 and decreased ACE protein in renal tubules from diabetic mice: a renoprotective combination? Hypertension 2004; 43: 1120-1125.

32. Yan L, Yang R, Cheng H, Fu Z, Zhong G, Yan T. Protective effect of the angiotensin-converting enzyme inhibitor perindopril on diabetic glomerulopathy in streptozotocin-induced diabetic rats. Chin Med J 1998; 111: 306-308.

33. Heilig CW, Concepcion LA, Riser BL, Freytag SO, Zhu M, Cortes $\mathrm{P}$. Overexpression of glucose transporters in rat mesangial cells cultured in a normal glucose milieu mimics the diabetic phenotype. J Clin Invest 1995; 96: 1802-1814.

34. Tschope C, Seidl U, Reinecke A, Riester U, Graf K, Schultheiss HP, et al. Kinins are involved in the antiproteinuric effect of angiotensin-converting enzyme inhibition in experimental diabetic nephropathy. Int Immunopharmacol 2003; 3: 335-344

35. Yasunaga S, Yonemochi H, Saikawa T, Sakata T. Bradykinin regulates captopril-induced upregulation of beta-adrenergic receptor in cultured neonatal rat cardiomyocytes. $J$ Mol Cell Cardiol 2000; 32: 153-159.

36. Lindberg BF, Gyllstedt E, Andersson KE. Conversion of angiotensin I to angiotensin II by chymase activity in human pulmonary membranes. Peptides 1997; 18: 847-853. 
37. Bertoluci MC, Uebel D, Schmidt A, Thomazelli FC, Oliveira FR, Schmid H. Urinary TGF-beta1 reduction related to a decrease of systolic blood pressure in patients with type 2 diabetes and clinical diabetic nephropathy. Diabetes Res Clin Pract 2006; 72: 258-264.
38. Lehfeld LS, Silveira LA, Ghini B, Lopes de Faria JB. Early blood pressure normalization independent of the class of antihypertensive agent prevents augmented renal fibronectin and albuminuria in experimental diabetic nephropathy. Kidney Blood Press Res 2004; 27: 114-120. 